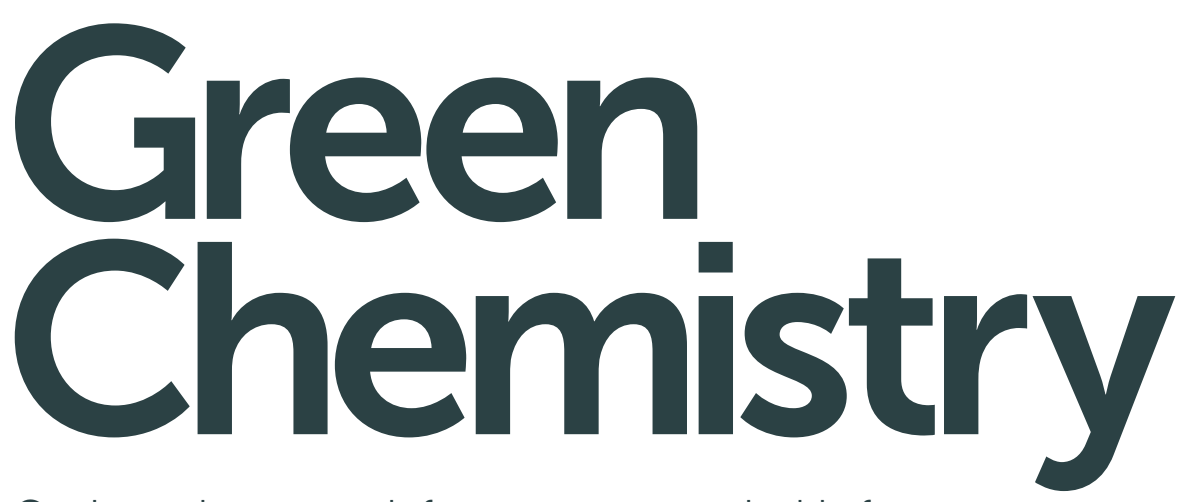

Cutting-edge research for a greener sustainable future www.rsc.org/greenchem

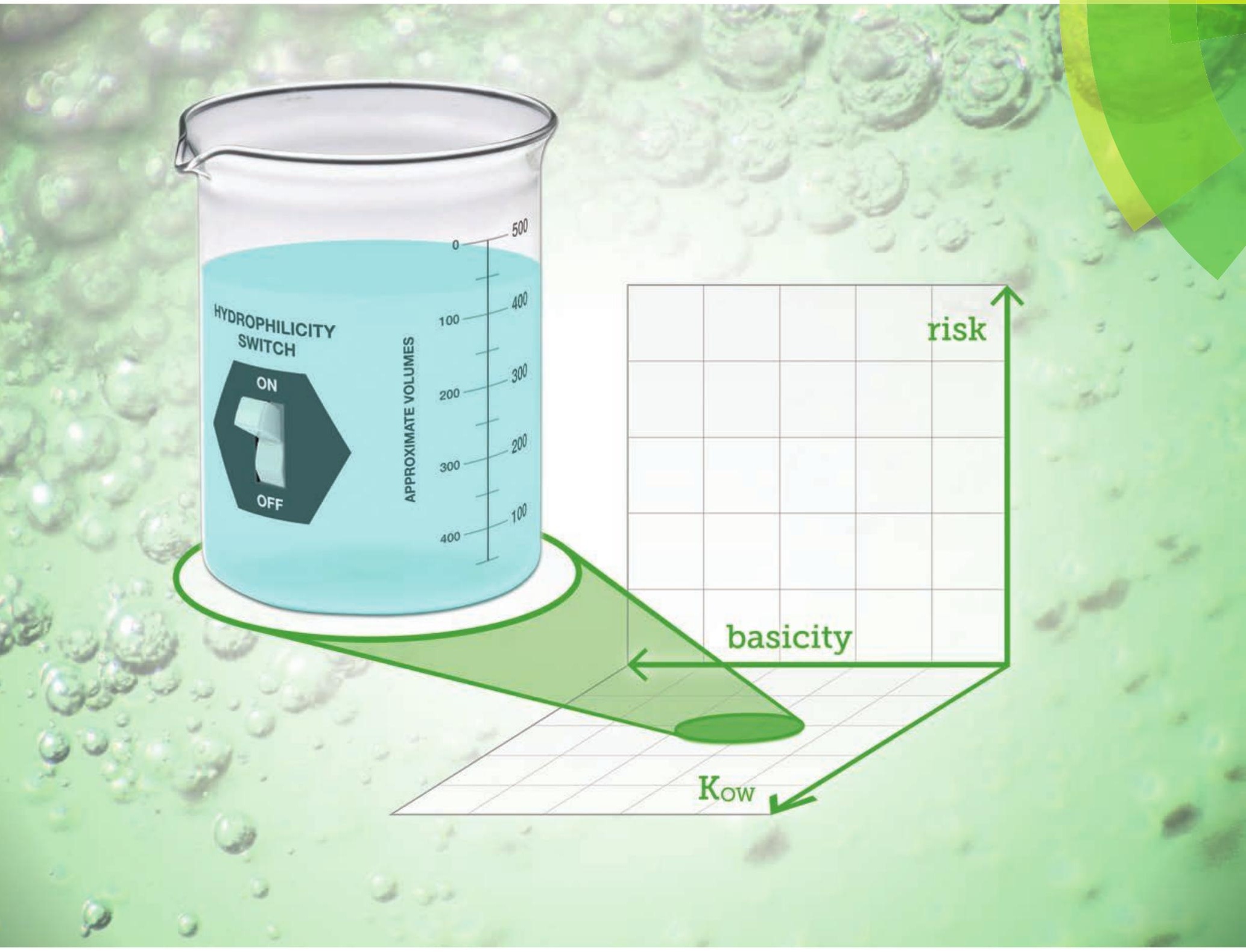

ISSN 1463-9262

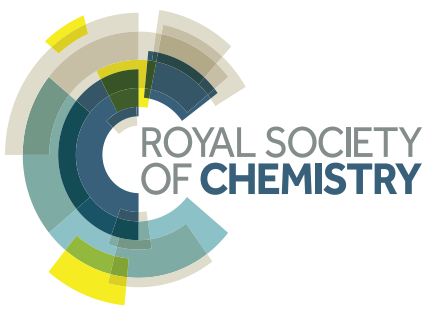




\section{Green Chemistry}

\section{PAPER}

Cite this: Green Chem., 2014, 16 1187

Received 19th October 2013, Accepted 18th December 2013 DOI: $10.1039 / c 3 g c 42164 c$

www.rsc.org/greenchem

\section{Design and evaluation of switchable-hydrophilicity solvents $\uparrow$}

\begin{abstract}
Jesse R. Vanderveen, Jeremy Durelle and Philip G. Jessop*
Switchable-hydrophilicity solvents (SHSs) are solvents that can switch reversibly between one form that is

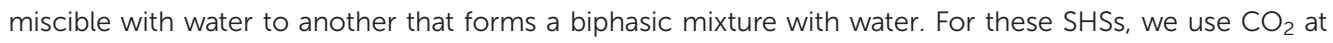
1 bar as a stimulus for triggering the transformation to the water-miscible form and removal of $\mathrm{CO}_{2}$ to achieve the reverse. We now report the identification of 13 new SHSs, including the first secondary amine SHSs, and a comparison of all known SHSs in terms of safety and environmental impacts. Amines which include another functional group, especially oxygen-containing groups, are less hazardous than alkylamines. Secondary amines can have improved switching speeds relative to tertiary amines. The variety of SHSs identified suggests that amine SHSs can be designed to have ideal properties for a given application.
\end{abstract}

\section{Introduction}

The widespread use of volatile solvents contributes to a variety of health, safety, and environmental problems such as inhalation toxicity, flammability, and smog formation. It is well known that non-volatile organic solvents avoid all of these problems, but they are rarely used in industry because they cannot be distilled. Distillation is the standard method for removing solvent from product at the end of almost any chemical process that uses solvents. Industry's dependence on distillation is responsible for the continued widespread use of volatile organic solvents despite their known hazards. The use of switchable-hydrophilicity solvents (SHSs), in combination with water, has been proposed as an alternative to distillation for solvent removal that does not require the use of volatile compounds. ${ }^{1-3}$

A SHS is a solvent which is poorly miscible with water in one form but completely miscible with water in another form and which can be switched between these two forms by a simple change in the system. Amidine and tertiary amine SHSs have been identified ${ }^{1,2}$ which can be switched between the two forms by the addition or removal of $\mathrm{CO}_{2}$ from the system. The change in miscibility is due to an acid-base reaction between either hydrated $\mathrm{CO}_{2}$ or carbonic acid in the carbonated water and the SHS, resulting in the hydrophilic bicarbonate salt of the protonated SHS (eqn (1)). This behaviour has been

Department of Chemistry, Queen's University, Kingston, Ontario, Canada, K7L $3 N 6$. E-mail: jessop@chem.queensu.ca; Fax: +1 (613) 533-6669; Tel: +1 (613) 533-3212 $\dagger$ Electronic supplementary information (ESI) available: ${ }^{13} \mathrm{C}\left\{{ }^{1} \mathrm{H}\right\}$ NMR spectra of secondary amine and carbonated water mixtures and analysis of the accuracy of TEST predictions. CCDC 967314. For ESI and crystallographic data in CIF or other electronic format see DOI: 10.1039/c3gc42164c exploited as a method for removing solvent from products such as soybean oil, ${ }^{1}$ algae oil, ${ }^{4,5}$ bitumen,${ }^{6}$ and high density polystyrene powder. ${ }^{2}$

$$
\mathrm{NR}_{3}+\mathrm{H}_{2} \mathrm{O}+\mathrm{CO}_{2} \rightleftharpoons \mathrm{NR}_{3} \mathrm{H}^{+}+\mathrm{HCO}_{3}{ }^{-}
$$

The first known SHSs contained amidine functional groups, but were found to be impractical solvents because they are expensive to manufacture. ${ }^{1,2}$ Eight tertiary amine SHSs were then identified which overcame this limitation. ${ }^{2}$ However, some of these SHSs have health and safety concerns associated with them, such as toxicity, volatility, or flammability, which would make them less desirable for use in an industrial setting. In this paper, we identify 13 new secondary and tertiary amine SHSs which are commercially available or easily prepared. The amines were selected in order to overcome one or more of the issues presented by previously confirmed SHSs. We compare all of the SHSs in terms of boiling point, flash point, eutrophication potential, toxicity, and effects on skin (where information is available) to identify the safest and most environmentally benign SHSs.

Before we could search for new SHSs, we needed to identify the properties of known SHSs and how they differ from compounds that are not SHS. Amines, amidines, and guanidines that have already been tested for SHS behaviour ${ }^{1,2}$ are listed in Table 1. If an organic liquid forms one phase when mixed with water before $\mathrm{CO}_{2}$ is added, the system is considered monophasic and therefore not an SHS. If an organic liquid forms two phases when mixed with water both before and after $\mathrm{CO}_{2}$ is added, the system is considered biphasic. If the mixture of organic compound and water forms two phases before $\mathrm{CO}_{2}$ is added and forms one phase after $\mathrm{CO}_{2}$ is added, it is an SHS. Some guanidines formed biphasic mixtures with water initially and became monophasic upon exposure to $\mathrm{CO}_{2}$, but could not 
Table 1 Amines, amidines, and guanidines previously tested for their ability to serve as SHSs at room temperature $\mathrm{r}^{1,2}$

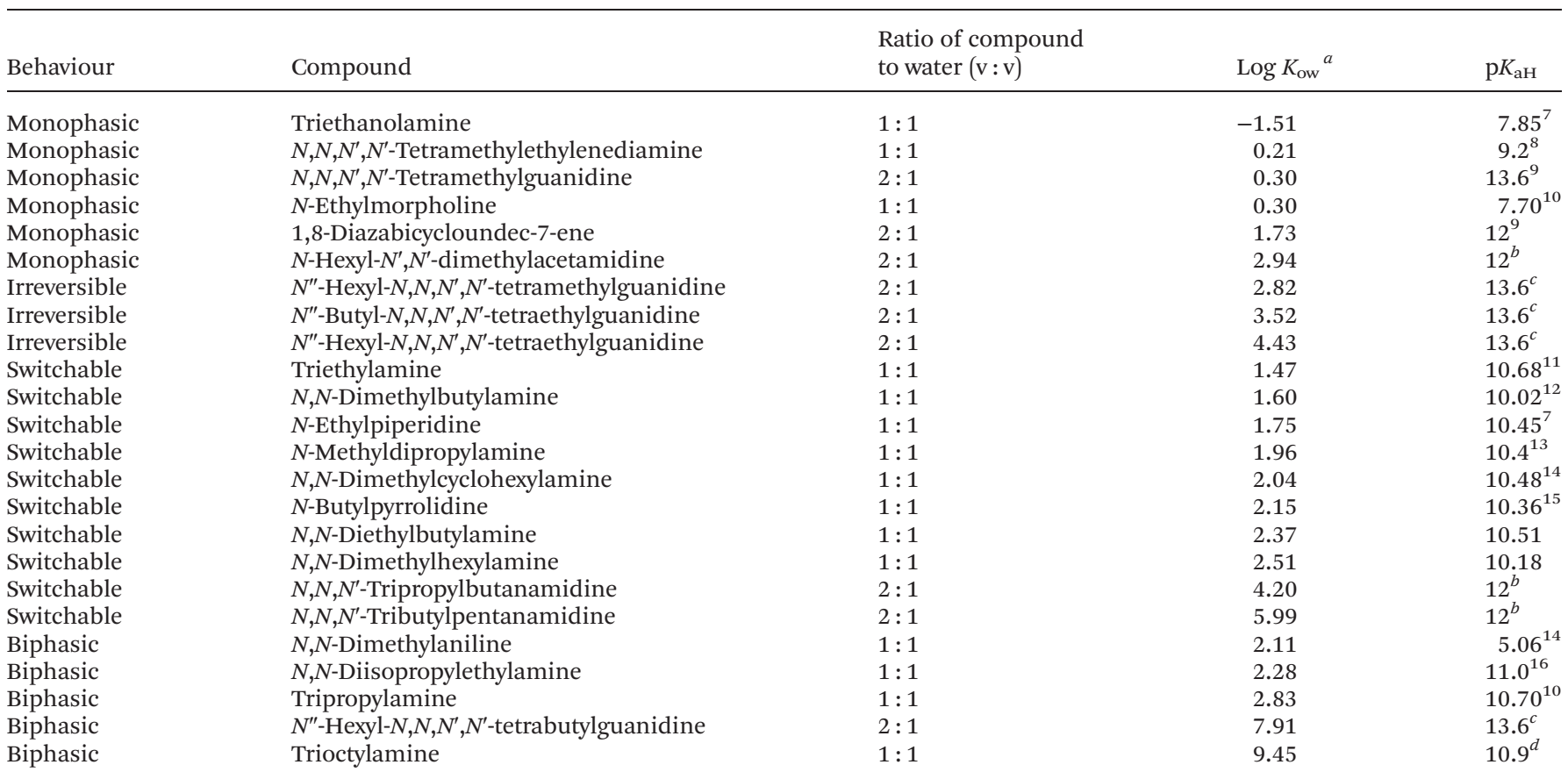

${ }^{a}$ Predicted using ALOGPS software version 2.1. ${ }^{17-19 ~}{ }^{b}$ Estimated to have a $\mathrm{p} K_{\mathrm{aH}}$ similar to 1,8-diazabicycloundec-7-ene. ${ }^{c}$ Estimated to have a p $K_{\mathrm{aH}}$ similar to $N, N, N^{\prime}, N^{\prime}$-tetramethylguanidine. ${ }^{d}$ Estimated to have a $\mathrm{p} K_{\mathrm{aH}}$ similar to tributylamine ( $\left.K_{\mathrm{aH}} 10.89\right) .{ }^{10}$

be reverted to biphasic mixtures, presumably because guanidines were far too basic. Compounds which displayed this behaviour are considered irreversible and were therefore rejected. The results of these tests are highly dependent on the proportions of water and organic solvent. The results shown in Table 1 were reported for $1: 1(\mathrm{v}: \mathrm{v})$ mixtures of water to amine or $2: 1(\mathrm{v}: \mathrm{v})$ mixtures of water to amidine or guanidines.

\section{Results and discussion}

\section{Selecting amines for switchable behaviour}

A variety of new amines were tested, but not all of them displayed SHS behaviour. Fig. 1 plots all the amines and amidines tested in this study and previous studies ${ }^{1,2}$ by the log of their octanol-water partition coefficient $\left(\log K_{\mathrm{ow}}\right)$ and the strength of their conjugate acids $\left(\mathrm{p} K_{\mathrm{aH}}\right)$. A trend was observed for the amines tested. First, the amine must have a $\log K_{\text {ow }}$ between approximately 1.2 and 2.5 in order to be a SHS. Amines with lower $\log K_{\text {ow }}$ were too hydrophilic and formed monophasic mixtures with water in their neutral form. Amines with higher $\log K_{\text {ow }}$ were too hydrophobic and formed biphasic mixtures with water even after exposure to $\mathrm{CO}_{2}$. This trend has been observed for previously identified tertiary amine SHSs. ${ }^{2}$ Also, most amines that displayed switchable miscibility with water had $\mathrm{p} K_{\mathrm{aH}}$ above 9.5. If an amine has insufficient basicity, it will not react with carbonated water enough for a switch from a biphasic to a monophasic mixture. Although SHSs met these criteria, some amines which were not SHSs met these criteria as well, suggesting that these are necessary but not sufficient

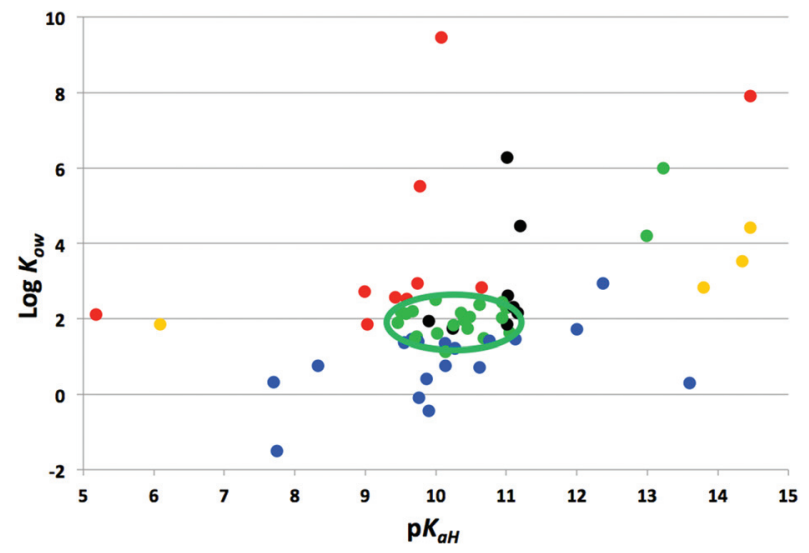

Fig. 1 All compounds tested for switchable miscibility with water at room temperature and 1:1 or 2:1 volume ratio of water to amine, plotted by their log $K_{\mathrm{ow}}$ and $\mathrm{p} K_{\mathrm{aH}}$ and coloured by their observed behaviour: monophasic (blue), irreversible (yellow), SHS (green), biphasic (red), and precipitation upon $\mathrm{CO}_{2}$ addition (black). All amine SHSs fall within the green oval. No oval is shown for the amidines because the boundaries of the acceptable area for amidines are unknown.

requirements for switchable behaviour. The two amidine SHSs did not fit these criteria (see the upper right portion of Fig. 1), and yet behaved as SHSs for reasons which are unclear.

\section{Amines with high boiling and flash points}

Non-volatile SHSs can be designed to capitalize on the previously described advantages of SHS separations. In order to reduce volatility, SHSs with large molecular weights are 
preferred, but increasing the molecular weights by simply extending the alkyl chains would increase the $\log K_{\text {ow }}$ excessively so that the bicarbonate salt of the amine would not be sufficiently soluble in carbonated water and the amine will therefore not be a SHS. By including hydrophilic functional groups in the structure of an amine while increasing the length of the alkyl chains, the solvent can be tailored to be less volatile and yet still fit within the $\log K_{\text {ow }}$ range required for SHS behaviour.

Hydrophilic functional groups also affect the basicity of the amine. The inductive effects of a functional group can decrease the $\mathrm{p} K_{\mathrm{aH}}$ of the amine, depending on the proximity of the group to the $\mathrm{N}$ centre. When designing a SHS with these functional groups, the exact positions of the amine and the electron withdrawing group must be considered so that the amine will be a sufficiently strong base to act as a SHS.

of the tertiary amines tested which incorporated other functional groups, six formed monophasic mixtures with water, five formed biphasic mixtures with water, and six displayed switchable miscibility (Table 2). These six new SHSs all followed the $\log K_{\mathrm{ow}}$ and $\mathrm{p} K_{\mathrm{aH}}$ criteria suggested in Fig. 1 except for $N, N$-dimethylbenzylamine. At a $1: 1$ volume ratio of water to amine, mixtures of water and $N, N$-dimethylbenzylamine remain biphasic even after prolonged bubbling of $\mathrm{CO}_{2}$ through solution. This behaviour is expected because $N, N$ dimethylbenzylamine $\left(\mathrm{p} K_{\mathrm{aH}}=9.03\right)$ is a weaker base than most SHSs and will not be sufficiently protonated by carbonated water to form a monophasic mixture with water at a $1: 1$ volume ratio. At a 5:1 volume ratio of water to amine, the amine displays switchable miscibility. Adding more water to the mixture increases the amount of amine in the aqueous phase enough to form a monophasic mixture after addition of $\mathrm{CO}_{2}$ without also resulting in a monophasic mixture when $\mathrm{CO}_{2}$

Table 2 Tertiary amines with other functional groups tested for switchable behaviour

\begin{tabular}{llcc}
\hline & & \multicolumn{2}{l}{$\log$} \\
Behaviour & Compound & $K_{\mathrm{ow}}{ }^{2}$ & \multicolumn{1}{c}{$\mathrm{p} K_{\mathrm{aH}}$} \\
\hline Monophasic & $N, N$-Dimethylaminoethanol & -0.44 & $9.31^{12}$ \\
Monophasic & $N, N$-Dimethylaminopropanol & -0.08 & $9.76^{20}$ \\
Monophasic & $N, N$-Diethylaminoethanol & 0.41 & $9.87^{12}$ \\
Monophasic & $N, N$-Diethylglycine methyl ester & 0.76 & 7.75 \\
Monophasic & $N, N$-Diethylaminopropanol & 0.77 & 10.39 \\
Monophasic & 5-(Diethylamino)pentan-2-one & 1.21 & $10.1^{21}$ \\
Monophasic & Ethyl 3-(diethylamino)propanoate & 1.40 & 9.35 \\
Switchable & Diisopropylaminoethanol & 1.16 & $10.14^{22}$ \\
Switchable & 4,4-Diethoxy- $N, N$ - & 1.48 & 9.83 \\
& dimethylbutanamine & & \\
Switchable & Ethyl 4-(diethylamino)butanoate & 1.82 & 10.15 \\
Switchable ${ }^{b}$ & $N, N$-Dimethylbenzylamine & 1.86 & $9.03^{11}$ \\
Switchable & 5-(Dipropylamino)pentan-2-one & 2.15 & 10.15 \\
Switchable & $N, N$-Dimethylphenethylamine & 2.18 & $9.51^{23}$ \\
Switchable & Dibutylaminoethanol & 2.20 & $9.67^{24}$ \\
Biphasic & Propyl 3-(diethylamino)propanoate & 1.85 & 9.45 \\
Biphasic & $N, N$-Dibutylaminopropanol & 2.56 & 10.5 \\
Biphasic & Ethyl 3(dipropylamino)propanoate & 2.72 & 9.29 \\
Biphasic & $N, N$-Dibutylaminobutanol & 2.93 & 10.7
\end{tabular}

${ }^{a}$ Predicted using ALOGPS software version 2.1. ${ }^{17-19} b$ At a $5: 1$ volume ratio of water to amine. ${ }^{c}$ At a $2: 1$ volume ratio of water to amine. is removed. Thus a liquid can be a SHS at one volume ratio, but not a SHS at another volume ratio.

The different functional groups investigated were alcohols, esters, ketones, acetals, and aromatic rings, each of which will affect the $\mathrm{p} K_{\mathrm{aH}}$ of the amine differently. Alcohols placed two carbons away from a tertiary amine do not lower the amine's $\mathrm{p} K_{\mathrm{aH}}$ enough to prevent an amino alcohol from displaying SHS behaviour. Aromatic rings must also be 2 carbons away from a tertiary amine for SHS behaviour to be observed at a 1:1 volume ratio of water to amine. $N, N$-Dimethylaniline $\left(\mathrm{p} K_{\mathrm{aH}}\right.$ 5.18 ) is not a strong enough base to have SHS behaviour, while $N, N$-dimethylbenzylamine ( $\mathrm{p} K_{\mathrm{aH}}$ 9.03) displays SHS behaviour in a $5: 1$ volume ratio of water to amine. Finally, $N, N$-dimethylphenethylamine $\left(\mathrm{p} K_{\mathrm{aH}}\right.$ 9.51) has SHS behaviour at a $1: 1$ volume ratio of water to amine. Ester groups must be 3 carbons away from a tertiary amine for an amino ester to display switchable miscibility, as evidenced by the glycine derivative and amino propanoates, which are not SHSs, and the amino butanoate, which is an SHS.

The SHSs identified in Table 2 are less volatile than trialkylamine SHSs. The SHSs with additional functional groups all have boiling points above $180{ }^{\circ} \mathrm{C}$ and predicted flash points above $50{ }^{\circ} \mathrm{C}$ (Table 4 , discussed later). By comparison, the least volatile trialkylamine SHS, $N, N$-dimethylcyclohexylamine, has a boiling point of $162^{\circ} \mathrm{C}$ and a flash point of $41^{\circ} \mathrm{C}$. The differences between the boiling and flash points of trialkylamine SHSs and SHSs with additional functional groups shows that the design strategy for less-volatile SHSs is successful.

\section{Secondary amines}

Secondary amines have an alternate reactivity pathway which allows them to uptake $\mathrm{CO}_{2}$ faster than tertiary amines. Like amidines and tertiary amines, secondary amines can be converted to bicarbonate salts upon exposure to carbon dioxide and water, but they can also undergo a direct reaction with carbon dioxide to form ammonium carbamate salts (eqn (2)). This alternative reaction occurs faster than the bicarbonate salt formation, so secondary amine SHSs are likely to switch faster than tertiary amines. ${ }^{25}$ However, the energy and temperature required to remove $\mathrm{CO}_{2}$ from an aqueous ammonium carbamate solution is much larger than that required to remove $\mathrm{CO}_{2}$ from an ammonium bicarbonate solution. ${ }^{25}$ Therefore, using a secondary amine SHS can be more energyintensive than using a tertiary amine SHS.

$$
2 \mathrm{R}_{2} \mathrm{NH}+\mathrm{CO}_{2} \rightleftharpoons \mathrm{R}_{2} \mathrm{NH}_{2}^{+}+\mathrm{R}_{2} \mathrm{NCOO}^{-}
$$

While the increased rate of reaction of secondary amines is appealing, the higher energy cost of regeneration is not, so it is important to prevent significant formation of carbamate salts of an SHS. Sterically hindered amines are known to either not form carbamates or form destabilized carbamates which are rapidly hydrolyzed to bicarbonates. ${ }^{25}$ Carbamates may form as a kinetic product before being converted to bicarbonates, allowing for rapid uptake of $\mathrm{CO}_{2}$ without the large energy requirements for removing $\mathrm{CO}_{2} \cdot{ }^{25}$ Therefore, a sterically 
hindered secondary amine SHS may switch rapidly without increased energy requirements.

Of the secondary amines tested for switchable behaviour, three formed monophasic mixtures with water, five formed biphasic mixtures with non-carbonated water but formed a precipitate upon exposure to $\mathrm{CO}_{2}$, and six displayed switchable miscibility (Table 3). X-ray crystallography of the precipitate formed from dibutylamine confirmed that it was the bicarbonate salt of the amine (Fig. 2). This result suggests that the bicarbonate salts of some secondary amines are not sufficiently soluble in water to make the amines useful as SHSs at a $1: 1$ volume ratio.

Increasing the temperature of the mixture or increasing the volume ratio of water to amine might result in complete dissolution of the bicarbonate salt in the water. A precipitate forms when $\mathrm{CO}_{2}$ is bubbled through a 1:1 mixture of water and propyl-3-(sec-butylamino)propanoate at room temperature. If the volume ratio is adjusted to $2: 1$ water to amine and the mixture is heated to $50{ }^{\circ} \mathrm{C}$, bubbling $\mathrm{CO}_{2}$ through the mixture forms a monophasic liquid; this can be returned to a biphasic mixture if argon is bubbled through it at $65{ }^{\circ} \mathrm{C}$. Other

Table 3 Secondary amines tested for switchable behaviour

\begin{tabular}{lllc}
\hline & & $\log$ & \\
Behaviour & Compound & $K_{\text {ow }}{ }^{2}$ & $\mathrm{pK}_{\mathrm{aH}}$ \\
\hline Monophasic & Diethylamine & 0.71 & $10.92^{7}$ \\
Monophasic & Ethyl 3-(tert-butylamino)propanoate & 1.38 & 10.09 \\
Monophasic & tert-Butylethylamine & 1.42 & 11.35 \\
Monophasic & Diisopropylamine & 1.46 & $11.07^{7}$ \\
Switchable & Ethyl 3-(sec-butylamino)propanoate & 1.53 & 9.73 \\
Switchable & Dipropylamine & 1.64 & $11.05^{11}$ \\
Switchable & Butyl 3-(isopropylamino)propanoate & 1.90 & 9.77 \\
Switchable & Propyl 3-(sec-butylamino)propanoate & 1.95 & 9.80 \\
Switchable & N-Propyl-sec-butylamine & 2.03 & 11.05 \\
Switchable & Di-sec-butylamine & 2.43 & $11.0^{27}$ \\
Precipitates & Ethyl 3-(isobutylamino)propanoate & 1.46 & 9.45 \\
Precipitates & Ethyl 4-(tert-butylamino)butanoate & 1.75 & 10.77 \\
Precipitates & tert-Butylisopropylamine & 1.84 & 11.39 \\
Precipitates & Dibutylamine & 2.61 & $11.28^{7}$ \\
Precipitates & Dihexylamine & 4.46 & $11.0^{28}$
\end{tabular}

${ }^{a}$ Predicted using ALOGPS software version 2.1. ${ }^{17-19}{ }^{b}$ Requires a $2: 1$ volume ratio of water to amine and solution must be heated to $50^{\circ} \mathrm{C}$.
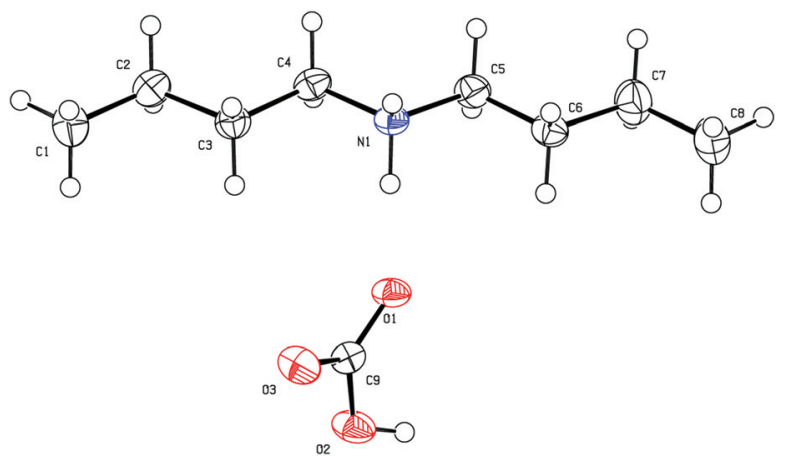

Fig. 2 The structure of dibutylammonium bicarbonate, recrystallized from the solid formed after bubbling $\mathrm{CO}_{2}$ through a dibutylamine-water mixture. secondary amines which form precipitates might display SHS behaviour under different conditions. Some secondary amines, such as $N$-propyl-sec-butylamine, form precipitates in carbonated water at room temperature but the heat released from the exothermic reaction of the amine and carbonated water can warm the solution enough to dissolve the bicarbonate salts completely.

Six secondary amines were confirmed to display SHS behaviour. With the exception of dipropylamine, each of these secondary amine SHSs contained sec-butyl or isopropyl groups to destabilize carbamate salts. Converting bicarbonate salts of sterically hindered secondary amine SHSs to $\mathrm{CO}_{2}$ and neutral amine was achieved at $65{ }^{\circ} \mathrm{C}$ while passing $\mathrm{N}_{2}$ through solution. Dipropylamine-water mixtures became biphasic upon heating to $65{ }^{\circ} \mathrm{C}$ even without bubbling $\mathrm{N}_{2}$ through solution, but the solution became monophasic again when cooled to room temperature. Dipropylamine's temperature-dependent miscibility with carbonated water has been observed before, ${ }^{26}$ but is not the desired behaviour for a SHS. When the solution was heated to $90{ }^{\circ} \mathrm{C}$ for $2 \mathrm{~h}$ without $\mathrm{N}_{2}$ passing through it, it became biphasic and remained biphasic when cooled to room temperature. The increased temperature requirement to remove $\mathrm{CO}_{2}$ from the solution is consistent with the formation of carbamate salts, as expected for sterically unhindered secondary amines such as dipropylamine. ${ }^{13} \mathrm{C}$ NMR analysis of carbonated water-dipropylamine solutions confirmed the presence of both bicarbonate salts and carbamate salts in solution, while no carbamates were observed for mixes of carbonated water with sterically-hindered secondary amine SHSs (see ESI $\dagger$ ).

Every secondary amine SHS, except di-sec-butylamine, switched from a biphasic solution to a monophasic solution after less than 10 min of bubbling $\mathrm{CO}_{2}$ through the solution, while tertiary amines switch after 20 to $120 \mathrm{~min}$. Di-sec-butylamine switched at a slower pace, comparable to tertiary amine SHSs. The two sec-butyl groups may be either decreasing the rate of carbamate formation substantially or preventing carbamate formation completely. Evidently, one branching group near the amine is enough to lower the energy requirements for removing $\mathrm{CO}_{2}$ while still allowing for a rapid switch from biphasic to monophasic solutions.

While most of these amines were only tested for one full switching cycle, we tested $\mathrm{CyNMe}_{2}$ and butyl 3-(isopropylamino)propanoate for their ability to handle multiple cycles. The former was used for many cycles without difficulty but the latter can only be used for one cycle, because of significant hydrolysis of the ester during the removal of the $\mathrm{CO}_{2}$. This problem may exist for other amino-esters as well.

\section{Risk evaluation of SHSs}

In order for SHSs to be considered for use industrially, it is important to consider their effects on health and the environment, preferably in comparison to the solvents that they would replace. In order to identify the safety and environmental effects of SHSs, the $\mathrm{LD}_{50}$ (oral, rat), boiling point, flash point, eutrophication potential (EP), and skin effects of all SHSs identified in this study and previous studies ${ }^{1,2}$ are compared 
in Table 4. The reported safety and environmental data reveal trends in the safety risks and environmental impacts of SHSs. We used hexane and toluene as representative conventional (non-switchable) solvents for comparison.

The toxicities of SHSs were compared using oral $\mathrm{LD}_{50}$ data (rat). Many SHSs do not have reported $\mathrm{LD}_{50}$ values. In these cases, the U.S. Environmental Protection Agency's Toxicity Estimation Software Tool (TEST) was used to predict oral $\mathrm{LD}_{50}$ values. ${ }^{29}$ We find that the predicted toxicities of amines are within a factor of 3 of reported $\mathrm{LD}_{50}$ values $95 \%$ of the time (see ESI $\dagger$ ). Despite the inherent inaccuracy of toxicity predictions, we expect that SHSs with predicted $\mathrm{LD}_{50}$ values above $2000 \mathrm{mg} \mathrm{kg}^{-1}$ are less toxic than SHSs with $\mathrm{LD}_{50}$ values of around $500 \mathrm{mg} \mathrm{kg}^{-1}$ or lower. Oxygen-containing SHSs have consistently higher $\mathrm{LD}_{50}$ values than dialkyl- and trialkylamine SHSs. Multiple different oral $\mathrm{LD}_{50}$ values have been reported for toluene. While toluene is less toxic than dialkyl- and trialkylamine SHSs, the varying reports of its $\mathrm{LD}_{50}$ and the uncertainty of the predicted $\mathrm{LD}_{50}$ values for other SHSs prevent us from drawing further conclusions. According to the $\mathrm{LD}_{50}$ data, hexane is much safer than every SHS. However, $\mathrm{LD}_{50}$ is a measure of acute toxicity, so solvents with chronic toxicity may appear safe even though they are not. For example, hexane is a known chronic neurotoxin, a serious problem that is not made evident by $\mathrm{LD}_{50}$ data. $^{30-32}$

The more volatile SHSs are not advantageous over toluene in terms of inhalation toxicity but the less volatile SHSs are probably much safer than toluene. There is little data regarding this form of toxicity for the SHSs. The inhalation $\mathrm{LC}_{50}$ values (rat, $4 \mathrm{~h}$ ) for triethylamine and dipropylamine are $4.1 \mathrm{~g} \mathrm{~m}^{-3}$ and $4.4 \mathrm{~g} \mathrm{~m}^{-3}$, respectively, ${ }^{33}$ while the corresponding values for toluene and hexane are $30.1 \mathrm{~g} \mathrm{~m}^{-3}$ and $169 \mathrm{~g} \mathrm{~m}^{-3}$, respectively. ${ }^{75,76}$ Dimethylcyclohexane has a reported $\mathrm{LC}_{50}$ (rat, $2 \mathrm{~h}$ ) of $1.9 \mathrm{~g} \mathrm{~m}^{-3} \cdot{ }^{33}$ The less-volatile SHSs may not pose an inhalation toxicity risk because their vapour pressures are much lower. For example the vapour pressure of propyl-3-(sec-butylamino)propanoate at $25{ }^{\circ} \mathrm{C}$ was estimated to be $13 \mathrm{~Pa}$ using a nomograph. By comparison, the vapour pressures of triethylamine, toluene, and hexane at $25{ }^{\circ} \mathrm{C}$ are 9670 $\mathrm{Pa},{ }^{77} 3804 \mathrm{~Pa},{ }^{78}$ and $20240 \mathrm{~Pa},{ }^{79}$ respectively. Propyl-3-(secbutylamino)propanoate and other low-volatility amines are less likely to be inhaled because of their low vapour pressure, making them less of an inhalation toxicity risk than volatile solvents.

The smell of amines depends greatly on the volatility and structure. Butyl-3-(iso-propylamino)propanoate, the least volatile SHS, has no detectable smell. Ethyl 4-(diethylamino)butanoate has a weak but pleasant smell. The volatile amines have the usual unpleasant smell one expects of amines.

The boiling and flash points of SHSs give an indication of the volatility of the solvents. Flash points also show how flammable solvents are. If the boiling point at atmospheric pressure is not known, a value was estimated by extrapolating from a reduced-pressure boiling point. The TEST program can

Table 4 Properties of known SHSs relating to safety hazards and environmental impacts of solvents

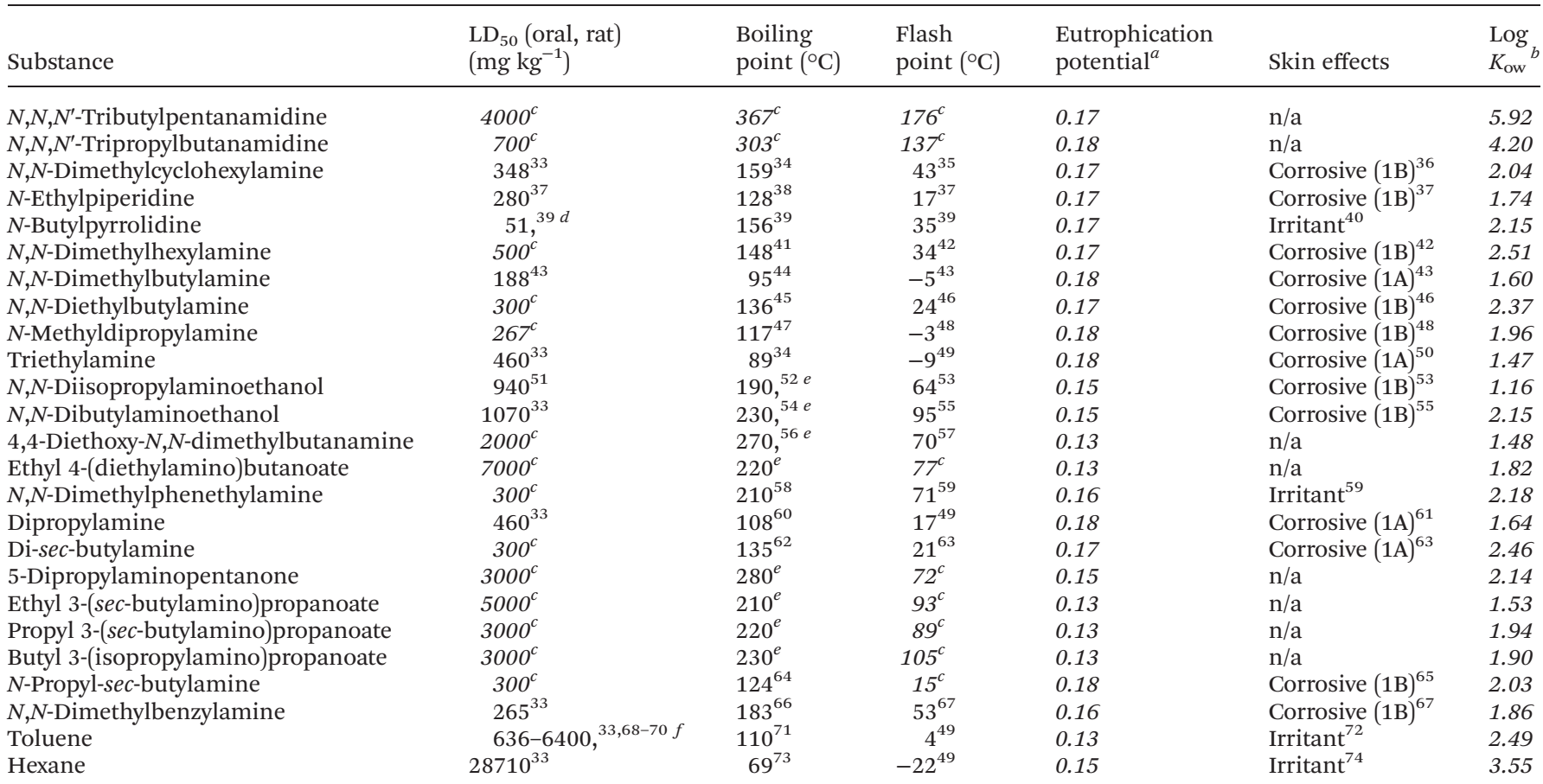

Estimated values are shown in italics. ${ }^{a}$ Calculated as mass equivalents of phosphate. ${ }^{b}$ Predicted using ALOGPS software version 2.1. ${ }^{17-19}$ ${ }^{c}$ Predicted using TEST software version 4.1. ${ }^{29}{ }^{d}$ Oral $\mathrm{LD}_{50}$ value for mice. ${ }^{e}$ Boiling point at atmospheric pressure extrapolated from boiling point at reduced-pressure. ${ }^{f}$ Several $\mathrm{LD}_{50}$ values have been reported for toluene. ${ }^{33,68-70}$ The reported $\mathrm{LD}_{50}$ value of $636 \mathrm{mg} \mathrm{kg}^{-1}$ may be the result of a miscalculation. ${ }^{69,70}$ 
be used to predict flash points if the flash point of an SHS is not known. These predictions are accurate to within $8^{\circ} \mathrm{C}, 81 \%$ of the time if the experimental flashpoint is above $20^{\circ} \mathrm{C}$ (see ESI $\dagger$ ). Almost every SHS is safer than toluene and hexane in terms of volatility and flammability. SHS containing another functional group in addition to an amine were designed to be less volatile and less flammable, and the data confirms that they are safer than other SHSs by these metrics. Under the UN globally-harmonized system of classification, these heavier SHSs would be classified as combustible rather than flammable liquids (flash points $>60{ }^{\circ} \mathrm{C}$ ). ${ }^{80}$

The eutrophication potential of the SHSs was calculated using a modified version of the equation described by Heijungs et al. ${ }^{81}$ replacing chemical oxygen demand with theoretical oxygen demand, which was calculated using an equation described by Baker, Milke and Mihelcic. ${ }^{82}$ The implications of these equations are that lower nitrogen content and higher oxygen content in a compound lowers its eutrophication potential. As a result, oxygen containing SHS have less eutrophication potential than other SHSs, with amino esters having the lowest potential. Indeed, amino ester SHSs have eutrophication potentials similar to toluene and lower than hexane, despite their nitrogen content.

Skin effects are another concern for SHSs; 13 of the SHSs are corrosive. In order to differentiate between different levels of corrosion, different classes of corrosion as defined by the Globally Harmonized System were used where information was available. ${ }^{80}$ A class $1 \mathrm{~A}$ corrosive substance shows effects after 3 minutes of exposure and less than 1 hour of observation. A class $1 \mathrm{~B}$ corrosive substance shows effects after 1 hour of exposure and less than 14 days of observation. Class $1 \mathrm{~A}$ corrosive SHSs should be avoided. Fortunately, two of the SHSs and many conventional solvents like toluene and hexane are irritants, rather than corrosive liquids. For many of the SHSs, skin effect data is unavailable.

Bioaccumulation is not a concern for SHSs. Compounds with $\log K_{\text {ow }}$ values below 3.5 are considered to have low bioaccumulation potential. ${ }^{83}$ All known amine SHSs have $\log K_{\mathrm{ow}}$ between approximately 1.2 and 2.5. The amidine SHSs would not bioaccumulate, despite their high $\log K_{\text {ow }}$ values, because they are hydrolytically unstable and therefore would not likely persist in the environment long enough to pose a bioaccumulation risk. Some conventional solvents (e.g. hexane) have moderate bioaccumulation potential, while others have low potential (e.g. toluene).

The use of volatile solvents results in volatile organic compound emissions and contributes to smog formation. ${ }^{84}$ With regards to this environmental concern, solvents are generally expected to be more benign if they are less volatile. SHSs with additional functional groups are much less volatile than conventional solvents like hexane and toluene. While volatile SHSs like triethylamine will have no advantages over conventional solvents, the low-volatility SHSs likely have less potential to contribute to smog formation than conventional solvents.

The persistence of a solvent when it is released into the environment is another concern. Compounds can degrade by a number of different pathways and it can be difficult to predict their persistence. However, some degradation trends relating to chemical structures have been observed. ${ }^{85}$ Quaternary carbon centres, extensive branching, heterocycles, and tertiary amines tend to decrease degradability. Features that increase degradability are oxygen atoms (particularly esters), unsubstituted alkyl chains of 4 or more, and unsubstituted phenyl rings. Secondary amine SHSs are also expected to be more biodegradable than tertiary amine SHSs. Howard et al. found that tertiary amines are poorly biodegradable. ${ }^{86}$ Eide-Haugmo et al. suggest that secondary amines are more degradable than tertiary amines. ${ }^{87}$ Although amine biodegradation data is sparse and many exceptions are apparent, the literature data does support the notion that secondary amines will biodegrade more readily than tertiary amines. ${ }^{86-91}$ For example, dipropylamine is biodegradable while triethylamine is not. ${ }^{91,92}$ Not all tertiary amines will persist however. The biodegradation of $\mathrm{N}, \mathrm{N}$-dimethylcyclohexylamine is not rapid, but it is considered to be biodegradable in an aqueous environment (ZahnWellens test). ${ }^{93}$ The available data also indicates that compounds with quaternary carbons are more resistant to biodegradation than straight chain compounds. A common opinion is that any branching will decrease biodegradability. However, Boethling et al. report that this is an oversimplification and only extensive branching and quaternary carbons show a trend of decreasing degradability. ${ }^{85}$ Many secondary amine SHS contain a branching group to destabilize carbamate formation. An ideal secondary amine SHS would include one branching group to destabilize the carbamate product without significantly decreasing its biodegradability.

With regard to this information, secondary amino ester SHSs are expected to be the least persistent, particularly butyl 3 -(isopropylamino)propanoate because it contains an $n$-butyl group. Tertiary amine SHSs containing other functional groups and dialkylamine SHSs are second choices, while trialkylamine SHSs will likely persist longer than the other SHSs. Toluene and hexane are both biodegradable. ${ }^{94,95}$ Trialkylamine SHSs should be more persistent than conventional solvents, but we expect secondary amine SHSs and tertiary amine SHS with a second functional group to have biodegradability comparable to or better than conventional solvents.

There are other considerations which can also be used to differentiate between SHSs. Some SHSs, such as the amino acetal, the aminoesters, and the amidines are prone to hydrolysis and are likely to degrade over time. Dipropylamine forms a stable carbamate salt and more energy must be put into the system to convert the salt back into $\mathrm{CO}_{2}$ and neutral amine. Some SHSs also require different amounts of water to display switchability. Most SHSs work at a 1:1 volume ratio, but some require a $2: 1$ or even $5: 1$ water-amine volume ratio. The amount of energy required to heat the water when removing $\mathrm{CO}_{2}$ increases as the amount of water increases. Some SHSs switch faster than others as well. In particular, secondary amines switch from biphasic to monophasic mixtures faster than tertiary amines. None of these factors are apparent from the information given in Table 4, but they can affect the overall viability of an SHS. 
While no SHS can be identified as being the most benign, the structural features that generate the most benign SHSs can be determined from the above trends. The data available for oxygen-containing SHSs suggest that they are less toxic and less volatile than di- and tri-alkyl amine SHSs. They are also no more corrosive and have lower eutrophication potentials, making them the most benign SHSs identified according to the metrics listed in this study. However, the risk of hydrolysis, which limit the reusability of aminoesters, suggests that they may not be ideal. The amidine SHSs also have favourable safety and environmental properties apart from a larger eutrophication potential and likely corrosivity, but they are unlikely ever to be used because of their high cost of synthesis. No differences between secondary and tertiary amine SHSs are apparent from the data in Table 4 , but the secondary amines are likely to be more biodegradable. Not every risk is identified in Table 4. There is insufficient data to comment on chronic toxicity or carcinogenicity. Because of these uncertainties, we do not recommend a single SHS as the most benign but rather we recommend consideration of all of their properties before one is used and more research including the identification of even better SHS.

\section{Conclusions}

Several new SHSs have been identified, including secondary amines and amines incorporating an additional functional group. Amines which display SHS behaviour typically have log $K_{\text {ow }}$ between 1.2 and 2.5 and $\mathrm{p} K_{\mathrm{aH}}$ above 9.5. Dimethylbenzylamine is an exception ( $\mathrm{p} K_{\mathrm{aH}}$ 9.03), but is only switchable if the volume of water is much larger than the volume of amine. Secondary amines can also display switchable behaviour but can form carbamate salts and precipitate as bicarbonate salts. Secondary amine SHSs can be designed to avoid significant carbamate formation by making them sterically hindered. Amines incorporating other functional groups are more benign than other SHSs, commonly having lower toxicity, volatility, flammability, and eutrophication potential. Compared to toluene, the secondary amine ester SHSs are predicted to be safer for health and the environment in terms of flammability, smog formation, inhalation toxicity, and bioaccumulation (lower $K_{\text {ow }}$ ). They are comparable to toluene in terms of eutrophication and possibly biodegradation. The variety of compounds identified and their different properties show that SHSs can be designed to meet the requirements of an application.

\section{Experimental}

Chemicals were used as received. Amines were commercially available (Sigma-Aldrich, TCI, Fisher) except for amino propanoate/butanoate esters and amino ketones, which were synthesized and characterized as described below. Argon
(99.998\%) and $\mathrm{CO}_{2}$ (chromatographic grade) were purchased from Praxair.

\section{Testing for switchable behaviour}

To confirm the switchable miscibility, amines were mixed with water in a $1: 1$ volume ratio. If two phases were observed, $\mathrm{CO}_{2}$ was bubbled into the solution through a gas dispersion tube (Ace Glass, 25-50 micron porosity) for $2 \mathrm{~h}$. If the mixture became monophasic, $\mathrm{N}_{2}$ was bubbled into the solution through a gas dispersion tube for $2 \mathrm{~h}$ while the solution was heated to $65{ }^{\circ} \mathrm{C}$. If the mixture became biphasic again, the amine was classified as a SHS. Other volume ratios were attempted for some amines.

\section{Evaluation}

Log $K_{\mathrm{ow}}$ values were predicted using ALOGPS 2.1. ${ }^{17-19} \mathrm{p} K_{\mathrm{aH}}$ values were found from literature or determined titrimetrically. Flash points, skin effects, and $\mathrm{LD}_{50}$ values were found from literature or MSDS. If flash point or $\mathrm{LD}_{50}$ values were unavailable, they were calculated using the TEST program. ${ }^{29}$ Eutrophication potentials (EP) were calculated using a variation of the method proposed by Heijungs et al., which calculates the eutrophication potential of a compound based on its molecular weight (MW), the number of phosphorus and nitrogen atoms it contains $\left(\nu_{\mathrm{P}}\right.$ and $\left.\nu_{\mathrm{N}}\right)$, and its theoretical oxygen demand $\left(\nu_{\text {ThOD }}\right)$ (eqn (3) and (4)). ${ }^{81}$ Theoretical oxygen demands were calculated using the method described by Baker, Milke, and Mihelcic (eqn (5) and (6)), ${ }^{82}$ which assumes that nitrogen atoms are converted to $\mathrm{NH}_{3}$ and that all carbon atoms are completely oxidized. The reference compound for eutrophication potential is $\mathrm{PO}_{4}{ }^{3-}$.

$$
\begin{gathered}
\nu_{\mathrm{tot}, i}=\left(\nu_{\mathrm{P}, i}+\nu_{\mathrm{N}, i} / 16+\nu_{\mathrm{ThOD}, i} / 138\right) \\
\mathrm{EP}_{i}=\frac{\nu_{\mathrm{tot}, i} / \mathrm{MW}_{i}}{\nu_{\mathrm{tot}, \mathrm{ref}} / \mathrm{MW}_{\mathrm{ref}}} \\
\mathrm{C}_{a} \mathrm{H}_{b} \mathrm{~N}_{c} \mathrm{O}_{d}+n \mathrm{O}_{2} \rightarrow a \mathrm{CO}_{2}+\frac{b-3 c}{2} \mathrm{H}_{2} \mathrm{O}+c \mathrm{NH}_{3} \\
\nu_{\text {ThOD }}=2 n=2 a+\frac{b-3 c}{2}-d
\end{gathered}
$$

\section{Dibutylammonium bicarbonate crystal formation}

Dibutylamine $(5 \mathrm{~mL})$ and water $(5 \mathrm{~mL})$ were combined in a vial. $\mathrm{CO}_{2}$ was bubbled through the mixture until a large quantity of precipitate formed. The mixture was heated to $40{ }^{\circ} \mathrm{C}$, resulting in a biphasic mixture with no solids. Upon cooling to room temperature, needle-like crystals formed at the interface between the liquid phases.

\section{Observation of secondary amine speciation in carbonated water}

Amine (dipropylamine, di-sec-butylamine, or sec-butylisopropylamine, $1 \mathrm{~mL}$ ) was mixed with $1 \mathrm{~mL} \mathrm{H}_{2} \mathrm{O}$ in a vial and $\mathrm{CO}_{2}$ was bubbled through the solution until it became monophasic. 
$\mathrm{CH}_{3} \mathrm{CN}(0.2 \mathrm{~mL})$ was added to solution as a reference compound and the solution was characterized by ${ }^{13} \mathrm{C}\left\{{ }^{1} \mathrm{H}\right\}$ NMR spectroscopy.

\section{Measuring the $\mathrm{p} K_{\mathrm{aH}}$ of amines}

For most amines, a $\sim 20 \mathrm{~mL}$ solution containing $\sim 0.02 \mathrm{~g}$ amine in distilled water was titrated with $\sim 0.1 \mathrm{M} \mathrm{HCl}$. The $\mathrm{pH}$ of the solution was recorded after each addition of titrant (Orion 4 Star $\mathrm{pH}$ meter, Thermo Scientific). The equivalence point was determined using a derivative plot and the $\mathrm{pH}$ at the half equivalence point was taken as the $\mathrm{p} K_{\mathrm{aH}}$ of the amine. Titrations were performed at least twice.

Dibutylaminobutanol and dibutylaminopropanol were not sufficiently soluble in water to measure their aqueous $\mathrm{p} K_{\mathrm{aH}}$ directly. The $\mathrm{p} K_{\mathrm{aH}}$ of these compounds were measured in ethanol-water solutions and extrapolated to a completely aqueous solution using the method described by Gowland and Schmid. ${ }^{96}$

\section{Synthesis}

Amino esters and ketones were synthesized using procedures adapted from literature for similar compounds. ${ }^{97,98}$ NMR spectra were collected on a Bruker Avance-500 or a Bruker Avance-300 NMR spectrometer. IR spectra were collected with a Varian 640 FT-IR spectrometer. Mass Spectra were collected with a Perkin Elmer Clarus $600 \mathrm{~T}$ mass spectrometer connected to a Perkin Elmer Clarus 680 gas chromatograph.

Ethyl 3-(diethylamino)propanoate. Ethyl acrylate $(9.2 \mathrm{~g}$, $0.092 \mathrm{~mol})$ and diethylamine $(6.7 \mathrm{~g}, 0.092 \mathrm{~mol})$ were added to a round bottom flask and stirred for $24 \mathrm{~h}$. Distillation under vacuum afforded the pure product (14.9 g, 94\% yield); bp 57-59 ${ }^{\circ} \mathrm{C}$ (4 torr): ${ }^{1} \mathrm{H}$ NMR $\left(300 \mathrm{MHz}, \mathrm{CDCl}_{3}\right) \delta 0.95(\mathrm{t}, J=$ $7.2 \mathrm{~Hz}, 6 \mathrm{H}), 1.18(\mathrm{t}, J=7.2 \mathrm{~Hz}, 3 \mathrm{H}), 2.36(\mathrm{t}, J=7.4,2 \mathrm{H}), 2.44$ (q, $J=7.2 \mathrm{~Hz}, 4 \mathrm{H}), 2.71(\mathrm{t}, J=7.4 \mathrm{~Hz}, 2 \mathrm{H}), 4.05(\mathrm{q}, J=7.2 \mathrm{~Hz}, 2 \mathrm{H})$; ${ }^{13} \mathrm{C}$ NMR $\left(300 \mathrm{MHz}, \mathrm{CDCl}_{3}\right) \delta 12.12,14.18,32.49,46.93,48.22$, 60.34, 172.75; $\nu_{\max }$ (ATR) $\mathrm{cm}^{-1}$ 2972, 2935, 2874, 2806, 1735 $(\mathrm{C}=\mathrm{O}), 1448,1371,1298,1251,1198,1118,1094,1048,984$, 856, 787; m/z (EI) 173 (6), 158 (15), 144 (3), 130 (3), 116 (1), 99 (1), 86 (100), 73 (6), 72 (6), 58 (15), 56 (10), 55 (15); Anal. Calcd for $\mathrm{C}_{9} \mathrm{H}_{19} \mathrm{NO}_{2}$ : C 62.39, $\mathrm{H} 11.05, \mathrm{~N}$ 8.09; found $\mathrm{C} 62.15$, $\mathrm{H}$ 11.05, N 8.07. The ${ }^{1} \mathrm{H}$ NMR data match literature values. ${ }^{97}$

Ethyl 3-(dipropylamino)propanoate. Using the same procedure as for ethyl 3-(diethylamino)propanoate, $4.0 \mathrm{~g}$ $(0.040 \mathrm{~mol})$ of ethyl acrylate yielded $6.2 \mathrm{~g}$ product (77\% yield); bp 76-77 ${ }^{\circ} \mathrm{C}$ (4 torr): ${ }^{1} \mathrm{H}$ NMR $\left(300 \mathrm{MHz}, \mathrm{CDCl}_{3}\right) \delta 0.80(\mathrm{t}, J=$ $7.4 \mathrm{~Hz}, 6 \mathrm{H}), 1.19(\mathrm{t}, J=7.1 \mathrm{~Hz}, 3 \mathrm{H}$ ), 1.38 (apparent sextet, $J=$ $7.4 \mathrm{~Hz}, 4 \mathrm{H}), 2.30$ (t, $J=7.4 \mathrm{~Hz}, 4 \mathrm{H}), 2.36$ (t, $J=7.4 \mathrm{~Hz}, 2 \mathrm{H}), 2.71$ $(\mathrm{t}, J=7.4 \mathrm{~Hz}, 2 \mathrm{H}), 4.06(\mathrm{q}, J=7.1 \mathrm{~Hz}, 2 \mathrm{H}) ;{ }^{13} \mathrm{C} \mathrm{NMR}(300 \mathrm{MHz}$, $\left.\mathrm{CDCl}_{3}\right) \delta 11.65,14.08,20.31,32.50,49.56,56.06,60.12,172.78$; $\nu_{\max }(\mathrm{ATR}) \mathrm{cm}^{-1}$ 2959, 2937, 2873, 2805, $1736(\mathrm{C}=\mathrm{O}), 1463$, $1371,1341,1301,1250,1192,1078,1053,855,791 ; \mathrm{m} / z$ (EI) 201 (9), 172 (100), 156 (2), 144 (12), 130 (4), 114 (59), 101 (6), 86 (13), 84 (27), 72 (26), 70 (12), 56 (10), 55 (26); Anal. Calcd for $\mathrm{C}_{11} \mathrm{H}_{23} \mathrm{NO}_{2}$ : C 65.62, H 11.52, N 6.96; found C 65.63, H 11.60, $\mathrm{N}$ 6.97. The ${ }^{1} \mathrm{H}$ NMR data matches literature values. ${ }^{97}$
Ethyl 4-(diethylamino)butanoate. Ethyl 4-bromobutanoate $(5.0 \mathrm{~g}, 0.026 \mathrm{~mol})$ and diethylamine $(8.8 \mathrm{~g}, 0.12 \mathrm{~mol})$ were added to a round bottom flask containing $20 \mathrm{ml}$ acetonitrile. The mixture was stirred at $65^{\circ} \mathrm{C}$ for $24 \mathrm{~h}$. The resulting solution was concentrated by distillation, added to $25 \mathrm{ml} 1 \mathrm{M}$ $\mathrm{NaOH}$, and extracted with $3 \times 25 \mathrm{ml}$ hexanes. Distillation under vacuum afforded the pure product $(3.20 \mathrm{~g}, 66 \%$ yield); bp $65{ }^{\circ} \mathrm{C}$ (4 torr): ${ }^{1} \mathrm{H}$ NMR $\left(300 \mathrm{MHz}, \mathrm{CDCl}_{3}\right) \delta 0.94(\mathrm{t}, J=7.1$ $\mathrm{Hz}, 6 \mathrm{H}), 1.19$ (t, $J=7.1 \mathrm{~Hz}, 3 \mathrm{H}), 1.70(\mathrm{p}, J=7.3 \mathrm{~Hz}, 2 \mathrm{H}), 2.26$ (t, $J=7.3 \mathrm{~Hz}, 2 \mathrm{H}), 2.37$ (t, $J=7.3 \mathrm{~Hz}, 2 \mathrm{H}), 2.4(\mathrm{q}, J=7.1 \mathrm{~Hz}, 4 \mathrm{H})$ 4.07 (q, $J=7.1 \mathrm{~Hz}, 2 \mathrm{H}) ;{ }^{13} \mathrm{C}$ NMR (300 MHz, $\left.\mathrm{CDCl}_{3}\right) \delta 11.81$, $14.17,22.39,32.20,46.81,52.08,60.01,173.61 ; \nu_{\max }$ (ATR) $\mathrm{cm}^{-1}$ 2969, 1735 (C=O), 1184; m/z (EI) 187 (6), 172 (3), 158 (1), 142 (12), 115 (5), 114 (6), 98 (2), 86 (100), 58 (9), 56 (5); Anal. Calcd for $\mathrm{C}_{10} \mathrm{H}_{21} \mathrm{NO}_{2}$ : C 64.12, $\mathrm{H} \mathrm{11.31,} \mathrm{N} \mathrm{7.48;} \mathrm{found} \mathrm{C}$ 64.12, $\mathrm{H} 11.44, \mathrm{~N} 7.48$.

Ethyl 3-(sec-butylamino)propanoate. Ethyl acrylate (4.5 g, $0.045 \mathrm{~mol})$ and $s e c$-butylamine $(6.6 \mathrm{~g}, 0.9 \mathrm{~mol})$ were added to a round bottom flask and stirred for $24 \mathrm{~h}$. Distillation afforded the pure product $\left(7.0 \mathrm{~g}, 89 \%\right.$ yield); bp: $65{ }^{\circ} \mathrm{C}$ (4 torr): ${ }^{1} \mathrm{H}$ NMR $\left(500 \mathrm{MHz} \mathrm{CDCl}_{3}\right) \delta 0.77(\mathrm{t}, J=7.4 \mathrm{~Hz}, 3 \mathrm{H}), 0.91(\mathrm{~d}, J=6.2 \mathrm{~Hz}$, $3 \mathrm{H}), 1.14(\mathrm{t}, J=7.2 \mathrm{~Hz}, 3 \mathrm{H}), 1.20(\mathrm{~m}, 1 \mathrm{H}), 1.35(\mathrm{~m}, 1 \mathrm{H}), 2.37(\mathrm{t}$, $J=6.6 \mathrm{~Hz}, 2 \mathrm{H}), 2.44$ (apparent sextet, $J=6.2 \mathrm{~Hz}, 1 \mathrm{H}), 2.75(\mathrm{~m}$, $2 \mathrm{H}), 4.02$ (q, $J=7.2 \mathrm{~Hz}, 2 \mathrm{H}) ;{ }^{13} \mathrm{C} \mathrm{NMR}\left(500 \mathrm{MHz}, \mathrm{CDCl}_{3}\right)$ $\delta 10.1,14.1,19.7,29.4,34.8,42.2,54.1,60.1,172.7 ; \nu_{\max }$ (ATR) $\mathrm{cm}^{-1} 3331(\mathrm{~N}-\mathrm{H}), 2963,2932,2875,1731(\mathrm{C}=\mathrm{O}), 1463,1372$, 1255, 1186, 1096, 1056, 1028, 788, 734; m/z (EI) 172, 158 (7), 144 (94), 130, (5), 112 (7), 98 (65), 86 (56), 84 (7), 70 (37), 56 (100); Anal. Calcd for $\mathrm{C}_{9} \mathrm{H}_{19} \mathrm{NO}_{2}$ : C 62.39, $\mathrm{H}$ 11.05, N 8.09; found C 62.29, H 11.29, N 8.04.

Ethyl 3-(tert-butylamino)propanoate. Using the same procedure as for ethyl 3-(sec-butylamino)propanoate, $1.9 \mathrm{~g}$ $(0.019 \mathrm{~mol})$ ethyl acrylate and $2.9 \mathrm{~g}(0.040 \mathrm{~mol})$ tert-butylamine yielded $1.7 \mathrm{~g}$ product (51\% yield); bp $62{ }^{\circ} \mathrm{C}$ (4 torr): ${ }^{1} \mathrm{H}$ NMR $\left(300 \mathrm{MHz}, \mathrm{CDCl}_{3}\right) \delta 1.05(\mathrm{~s}, 9 \mathrm{H}), 1.21(\mathrm{t}, J=7.1 \mathrm{~Hz}, 2 \mathrm{H}), 2.43(\mathrm{t}$, $J=6.6 \mathrm{~Hz}, 2 \mathrm{H}), 2.77(\mathrm{t}, J=6.6 \mathrm{~Hz}, 2 \mathrm{H}), 4.09(\mathrm{q}, J=7.1 \mathrm{~Hz}, 2 \mathrm{H})$; ${ }^{13} \mathrm{C}$ NMR (300 MHz, $\mathrm{CDCl}_{3}$ ) $\delta 14.1,28.9,35.5,38.0,50.3,60.2$, 172.9; $\nu_{\max }(\mathrm{ATR}) \mathrm{cm}^{-1} 3319(\mathrm{~N}-\mathrm{H}), 2964,2868,1731(\mathrm{C}=\mathrm{O})$, 1362, 1230, 1174, 1099, 102; m/z (EI), 173 (1), 158 (94), 144 (3), 130 (4), 116 (5), 112 (31), 86 (50), 70 (100), 58 (20), 57 (21), 56 (11), 55 (19); Anal. Calcd for $\mathrm{C}_{9} \mathrm{H}_{19} \mathrm{NO}_{2}$ : C 62.39, $\mathrm{H}$ 11.05, N 8.09; found C 62.28, H 11.13, N 8.07.

Ethyl 3-(isobutylamino)propanoate. Using the same procedure as for ethyl 3-(sec-butylamino)propanoate, $1.9 \mathrm{~g}$ $(0.019 \mathrm{~mol})$ ethyl acrylate and $3.1 \mathrm{~g}(0.042 \mathrm{~mol})$ isobutylamine yielded $2.4 \mathrm{~g}$ product (73\% yield); bp: $68{ }^{\circ} \mathrm{C}$ (4 torr): ${ }^{1} \mathrm{H}$ NMR $\left(300 \mathrm{MHz}, \mathrm{CDCl}_{3}\right) \delta 0.88(\mathrm{~d}, J=6.6 \mathrm{~Hz}, 6 \mathrm{H}), 1.24(\mathrm{t}, J=7.1 \mathrm{~Hz}$, $3 \mathrm{H}$ ), 1.36 (broad, 1H) 1.71 (apparent nonet, $J=6.7 \mathrm{~Hz}, 1 \mathrm{H}$ ), $2.40(\mathrm{~d}, J=6.8 \mathrm{~Hz}, 2 \mathrm{H}), 2.48(\mathrm{t}, J=6.5 \mathrm{~Hz}, 2 \mathrm{H}), 2.84(\mathrm{t}, J=6.5$ $\mathrm{Hz}, 2 \mathrm{H}), 4.12(\mathrm{q}, J=7.1 \mathrm{~Hz}, 2 \mathrm{H}) ;{ }^{13} \mathrm{C} \mathrm{NMR}\left(300 \mathrm{MHz}, \mathrm{CDCl}_{3}\right) \delta$ $14.1,20.6,28.3,34.8,45.1,57.7,60.2,173.1 ; \nu_{\max }$ (ATR) $\mathrm{cm}^{-1}$ $3338(\mathrm{~N}-\mathrm{H}), 2954,2871,2821,1731(\mathrm{C}=\mathrm{O}), 1467,1372,1254$, 1186, 1121, 1061, 1029, 750; m/z (EI) 173 (3), 130 (70), 116 (7), 86 (38), 84 (100), 70 (7), 57 (13), 56 (9), 55 (9); Anal. Calcd for $\mathrm{C}_{9} \mathrm{H}_{19} \mathrm{NO}_{2}$ : C 62.39, H 11.05, N 8.09; found C 62.26, H 11.23, $\mathrm{N} 8.04$. 
5-(Diethylamino)pentan-2-one. Using the same procedure as for ethyl 4-(diethylamino)butanoate, $6.35 \mathrm{~g}$ (0.0526 mol) 5-chloropentan-2-one and $19.2 \mathrm{~g}(0.263 \mathrm{~mol})$ diethylamine yielded $0.3488 \mathrm{~g}$ of 5 -(diethylamino)pentan-2-one (20\% yield); bp $66{ }^{\circ} \mathrm{C}$ (4 torr): ${ }^{1} \mathrm{H}$ NMR (500 $\left.\mathrm{MHz}, \mathrm{CDCl}_{3}\right) \delta 0.95(\mathrm{t}, J=$ $7.1 \mathrm{~Hz}, 6 \mathrm{H}), 1.67(\mathrm{p}, 7.2 \mathrm{~Hz}, 2 \mathrm{H}), 2.10(\mathrm{~s}, 3 \mathrm{H}), 2.34(\mathrm{t}, J=$ $7.2 \mathrm{~Hz}, 2 \mathrm{H}), 2.41$ (t, $J=7.2 \mathrm{~Hz}, 2 \mathrm{H}), 2.45$ (q, $J=7.1 \mathrm{~Hz}, 4 \mathrm{H}) ;{ }^{13} \mathrm{C}$ NMR (500 MHz, $\left.\mathrm{CDCl}_{3}\right) \delta 11.67,21.24,29.93,41.48,46.71$, 51.94, 208.83; $\nu_{\max }$ (ATR) $\mathrm{cm}^{-1} 2968,2934,2874,2800,1714$ $(\mathrm{C}=\mathrm{O}), 1410,1361,1294,1202,1175,1121,1069,961,764$, 714; m/z (EI) 157 (4), 142 (1), 99 (4), 86 (100), 72 (2), 71 (2), 70 (2), 58 (12), 56 (5); HRMS (EI): $\mathrm{C}_{9} \mathrm{H}_{19} \mathrm{NO}$ for $\mathrm{M}^{+}$calculated 157.1467, found 157.1462.

5-(Dipropylamino)pentan-2-one. Using the same procedure as for ethyl 4-(diethylamino)butanoate, $3.95 \mathrm{~g}$ (0.0328 mol) 5chloro-pentan-2-one and $11.09 \mathrm{~g}(0.110 \mathrm{~mol})$ dipropylamine yielded $1.2204 \mathrm{~g}$ of 5 -(dipropylamino)-pentan-2-one $(20 \%$ yield); bp $96{ }^{\circ} \mathrm{C}$ (4 torr): ${ }^{1} \mathrm{H}$ NMR $\left(500 \mathrm{MHz}, \mathrm{CDCl}_{3}\right) \delta 0.85$ (t, $J=7.4 \mathrm{~Hz}, 6 \mathrm{H}$ ), 1.41 (apparent sextet, $J=7.4 \mathrm{~Hz}, 4 \mathrm{H}$ ), 1.68 (p, $J=7.1 \mathrm{~Hz}, 2 \mathrm{H}), 2.12(\mathrm{~s}, 3 \mathrm{H}), 2.32$ (multiplet, $6 \mathrm{H}), 2.37$ (t, $J=7.2$ $\mathrm{Hz}, 2 \mathrm{H}), 2.45$ (t, 2H, $J=7.2 \mathrm{~Hz}) ;{ }^{13} \mathrm{C} \mathrm{NMR}\left(500 \mathrm{MHz}, \mathrm{CDCl}_{3}\right) \delta$ $11.85,20.23,21.36,29.88,41.31,53.14,56.02,208.86$; $\nu_{\max }$ (ATR) $\mathrm{cm}^{-1}$ 2957, 2872, 2800, $1715(\mathrm{C}=\mathrm{O}), 1462,1362,1174$, 1078, 1020, 960, 746; m/z (EI) 185 (8), 156 (37), 154 (1), 140 (1), 127 (2), 114 (64), 98 (3), 85 (100), 72 (22), 70 (6), 56 (5); HRMS (EI): $\mathrm{C}_{11} \mathrm{H}_{23} \mathrm{NO}$ for $\mathrm{M}^{+}$calculated 185.1780, found 185.1775.

Ethyl 4-(tert-butylamino)butanoate. Ethyl 4-bromobutanoate $(6.8 \mathrm{~g}, 0.035 \mathrm{~mol})$ and tert-butylamine $(5.1 \mathrm{~g}, 0.070 \mathrm{~mol})$ were added to a round bottom flask containing $20 \mathrm{ml}$ acetonitrile. The mixture was stirred at $70{ }^{\circ} \mathrm{C}$ under a nitrogen atmosphere for $48 \mathrm{~h}$. The resulting solution was concentrated by distillation, added to $20 \mathrm{ml} 4 \mathrm{M} \mathrm{NaOH}$, and extracted with $3 \times 20 \mathrm{ml}$ pentane. Distillation afforded the pure product (3.9 g, 60\% yield); bp $72{ }^{\circ} \mathrm{C}$ (4 torr): ${ }^{1} \mathrm{H}$ NMR (300 MHz, $\mathrm{CDCl}_{3}$ ) $\delta 0.51$ (broad, 1H), $0.96(\mathrm{~s}, 9 \mathrm{H}), 1.13(\mathrm{t}, J=7.1 \mathrm{~Hz}, 3 \mathrm{H}), 1.64(\mathrm{p}$, $J=7.2 \mathrm{~Hz}, 2 \mathrm{H}), 2.24(\mathrm{t}, J=7.3 \mathrm{~Hz}, 2 \mathrm{H}), 2.45(\mathrm{t}, J=7.1 \mathrm{~Hz}, 2 \mathrm{H})$, $4.00(\mathrm{q}, J=7.1 \mathrm{~Hz}, 2 \mathrm{H}) ;{ }^{13} \mathrm{C} \mathrm{NMR}\left(300 \mathrm{MHz}, \mathrm{CDCl}_{3}\right) \delta$ 14.10, 26.36, 28.93, 32.20, 41.69, 50.01, 59.99, 173.40; $\nu_{\max }$ (ATR) 3452 $(\mathrm{N}-\mathrm{H}), 2963,1732(\mathrm{C}=\mathrm{O}), 1447,1366,1229,1159,1102,1030$, 768, 708; m/z (EI) 187 (1), 172 (100), 158 (1), 142 (3), 126 (31), 115 (25), 98 (5), 86 (82), 84 (17), 69 (17), 57 (33); Anal. Calcd for $\mathrm{C}_{10} \mathrm{H}_{21} \mathrm{NO}_{2}$ : C 64.12, $\mathrm{H} 11.31, \mathrm{~N} 7.48$; found $\mathrm{C} 63.94, \mathrm{H} 11.54$, N 7.47.

Propyl 3-(sec-butylamino)propanoate. Using the same procedure as for ethyl 3-(sec-butylamino)propanoate, $2.1 \mathrm{~g}$ $(0.021 \mathrm{~mol})$ of propyl acrylate and $2.7 \mathrm{~g}(0.037 \mathrm{~mol})$ of $\mathrm{sec}$-butylamine yielded $3.2 \mathrm{~g}$ of product $\left(92.7 \%\right.$ yield); bp $74{ }^{\circ} \mathrm{C}$ (4 torr): ${ }^{1} \mathrm{H} \mathrm{NMR}\left(500 \mathrm{MHz}, \mathrm{CDCl}_{3}\right) \delta 0.87(\mathrm{t}, J=7.4 \mathrm{~Hz}, 3 \mathrm{H}), 0.93(\mathrm{t}, J=$ $7.4 \mathrm{~Hz}, 3 \mathrm{H}), 1.01(\mathrm{~d}, J=6.3 \mathrm{~Hz}, 3 \mathrm{H}), 1.30(\mathrm{~m}, 1 \mathrm{H}), 1.46(\mathrm{~m}, 1 \mathrm{H})$, 1.64 (apparent sextet, $J=7.1 \mathrm{~Hz}, 3 \mathrm{H}), 2.49(\mathrm{t}, J=6.5 \mathrm{~Hz}, 2 \mathrm{H}$ ), $2.54(\mathrm{~m}, 1 \mathrm{H}), 2.86(\mathrm{~m}, 2 \mathrm{H}), 4.03(\mathrm{t}, J=6.7 \mathrm{~Hz}, 2 \mathrm{H}) ;{ }^{13} \mathrm{C} \mathrm{NMR}$ $\left(500 \mathrm{MHz}, \mathrm{CDCl}_{3}\right) \delta 10.15,10.37,19.75,21.94,29.43,34.96$, 42.39, 54.25, 66.02, 172.95; $\nu_{\max }($ ATR $) \mathrm{cm}^{-1} 3323(\mathrm{~N}-\mathrm{H}), 2964$, 2934, 2878, $1731(\mathrm{C}=\mathrm{O}), 1463,1377,1356,1259,1186,1099$, 1063, 1002, 736; m/z (EI) 187 (1), 186 (1), 172 (8), 158 (100), 144 (1), 130 (8), 128 (6), 116 (9), 112 (8), 98 (65), 86 (60), 84 (8),
72 (15), 70 (36), 56 (98); Anal. Calcd for $\mathrm{C}_{10} \mathrm{H}_{21} \mathrm{NO}_{2}$ : C 64.12, $\mathrm{H}$ 11.31, N 7.48; found C 64.01, H 11.54, N 7.46.

Butyl 3-(isopropylamino)propanoate. Using the same procedure as for ethyl 3-(sec-butylamino)propanoate, $4.7 \mathrm{~g}$ $(0.037 \mathrm{~mol})$ of propyl acrylate and $7.2 \mathrm{~g}(0.1 .221 \mathrm{~mol})$ of secbutylamine yielded $6.5 \mathrm{~g}$ of product (94.3\% yield); bp $83{ }^{\circ} \mathrm{C}$ (4 torr): ${ }^{1} \mathrm{H}$ NMR (500 MHz, $\mathrm{CDCl}_{3}$ ) $\delta 0.86(\mathrm{t}, J=7.4 \mathrm{~Hz}, 3 \mathrm{H})$, $0.98(\mathrm{~d}, J=6.3 \mathrm{~Hz}, 6 \mathrm{H}), 1.31$ (apparent sextet, $J=7.5 \mathrm{~Hz}, 2 \mathrm{H}$ ) $1.54(\mathrm{p}, J=7.1,2 \mathrm{H}), 2.43(\mathrm{t}, J=6.6 \mathrm{~Hz}, 2 \mathrm{H}), 2.74$ (septet, $J=$ $6.3 \mathrm{~Hz}, 1 \mathrm{H}), 2.80(\mathrm{t}, J=6.6 \mathrm{~Hz}, 2 \mathrm{H}), 4.02(\mathrm{t}, J=6.7 \mathrm{~Hz}, 2 \mathrm{H}) ;{ }^{13} \mathrm{C}$ NMR (500 MHz, $\left.\mathrm{CDCl}_{3}\right) \delta 13.54,19.10,22.85,30.60,34.87$, 42.49, 48.31, 64.20, 172.76; $\nu_{\max }(\mathrm{ATR}) \mathrm{cm}^{-1} 3331(\mathrm{~N}-\mathrm{H}), 2960$, 2873, $1731(\mathrm{C}=\mathrm{O}), 1467,1379,1337,1262,1173,1148,1064$, 1021, 840, 739; m/z (EI) 187 (2), 186 (2), 172 (70), 144 (14), 130 (4), 116 (13), 114 (17), 98 (64), 88 (10), 72 (100), 70 (22), 56 (89); Anal. Calcd for $\mathrm{C}_{10} \mathrm{H}_{21} \mathrm{NO}_{2}$ : C 64.12, $\mathrm{H}$ 11.31, N 7.48; found C 64.08, H 11.45, N 7.49.

Propyl 3-(diethylamino)propanoate. Using the same procedure as for ethyl 3-(diethylamino)propanoate, $1.2 \mathrm{~g}$ $(0.011 \mathrm{~mol})$ propyl acrylate and $1.4 \mathrm{~g}(0.019 \mathrm{~mol})$ of diethylamine yielded $1.6 \mathrm{~g}$ of product (85\% yield); bp $67^{\circ} \mathrm{C}$ (4 torr): ${ }^{1} \mathrm{H} \mathrm{NMR}\left(500 \mathrm{MHz}, \mathrm{CDCl}_{3}\right) \delta 0.94(\mathrm{t}, J=7.4 \mathrm{~Hz}, 3 \mathrm{H}), 1.02(\mathrm{t}, J=$ $7.2 \mathrm{~Hz}, 6 \mathrm{H}), 1.64$ (apparent sextet, $J=7.1 \mathrm{~Hz}, 2 \mathrm{H}), 2.44(\mathrm{t}, J=$ $7.5 \mathrm{~Hz}, 2 \mathrm{H}$ ), 2.51 (q, $J=7.2 \mathrm{~Hz}, 4 \mathrm{H}), 2.79(\mathrm{t}, J=7.5 \mathrm{~Hz}, 2 \mathrm{H})$, $4.03(\mathrm{t}, J=6.7 \mathrm{~Hz}, 2 \mathrm{H}) ;{ }^{13} \mathrm{C} \mathrm{NMR}\left(500 \mathrm{MHz}, \mathrm{CDCl}_{3}\right) \delta 10.36$, $11.85,21.96,32.30,46.80,48.12,65.94,172.96$; $\nu_{\max }$ (ATR) $\mathrm{cm}^{-1}$ 2968, 2937, 2878, 2805, $1735(\mathrm{C}=\mathrm{O}), 1465,1382,1266$, 1198, 1178, 1062, 996, 909; m/z (EI) 187 (6), 172 (17), 158 (2), 144 (1), 130 (6), 128 (3), 100 (1), 99 (1), 98 (1), 86 (100), 73 (17), 70 (2), 58 (17), 55 (2); Anal. Calcd for $\mathrm{C}_{10} \mathrm{H}_{21} \mathrm{NO}_{2}$ : C 64.12, H 11.31, N 7.48; found C 63.94, H 11.46, N 7.46.

\section{Acknowledgements}

We thank Switchable Solutions Inc. and the National Science and Engineering Research Council for financial support, Dr Preston Chase and Dr Lowy Gunnewiek for useful discussions, and the Canada Research Chairs program.

\section{Notes and references}

1 P. G. Jessop, L. Phan, A. Carrier, S. Robinson, C. J. Dürr and J. R. Harjani, Green Chem., 2010, 12, 809-814.

2 P. G. Jessop, L. Kozycz, Z. G. Rahami, D. Scheonmakers, A. R. Boyd, D. Wechsler and A. M. Holland, Green Chem., 2011, 13, 619-623.

3 P. G. Jessop, L. N. Phan, A. J. Carrier, R. Resendes and D. Wechsler, PCT Intl WO2011050469, 2011.

4 A. R. Boyd, P. Champagne, P. J. McGinn, K. M. MacDougall, J. E. Melanson and P. G. Jessop, Bioresour. Technol., 2012, 118, 628-632.

5 C. Samori, D. L. Barreiro, R. Vet, L. Pezzolesi, D. W. F. Brilman, P. Galletti and E. Tagliavini, Green Chem., 2013, 15, 353-356. 
6 A. Holland, D. Wechsler, A. Patel, B. M. Molloy, A. R. Boyd and P. G. Jessop, Can. J. Chem., 2012, 90, 805-810.

7 N. F. Hall and M. R. Sprinkle, J. Am. Chem. Soc., 1932, 54, 3469-3485.

8 U. Oesch, Z. Brzozka, A. Xu, B. Rusterholz, G. Suter, H. V. Pham, D. H. Welti, D. Ammann, E. Pretsch and W. Simon, Anal. Chem., 1986, 58, 2285-2289.

9 C. Wiles and P. Watts, Beilstein J. Org. Chem., 2011, 7, 13601371.

10 H. K. Hall, J. Phys. Chem., 1956, 60, 63-70.

11 V. Frenna, N. Vivona, G. Consiglio and D. Spinelli, J. Chem. Soc., Perkin Trans. 2, 1985, 1865-1868.

12 M. M. Kreevoy and S.-W. Oh, J. Am. Chem. Soc., 1973, 95, 4805-4810.

13 R. E. McMahon and N. R. Easton, J. Med. Pharm. Chem., 1961, 4, 423-586.

14 J. M. Devereux, K. R. Payne and E. R. A. Peeling, J. Chem. Soc., 1957, 2845-2851.

15 L. C. Craig and R. M. Hixon, J. Am. Chem. Soc., 1931, 53, 4367-4372.

16 S. Jarmelo, N. Maiti, V. Anderson, P. R. Carey and R. Fausto, J. Phys. Chem. A, 2005, 109, 2069-2077.

17 I. V. Tetko and V. Y. Tanchuk, J. Chem. Inf. Comput. Sci., 2002, 42, 1136-1145.

18 I. V. Tetko, J. Gasteiger, R. Todeschini, A. Mauri, D. Livingstone, P. Ertl, V. A. Palyulin, E. V. Radchenkco, N. S. Zefirov, A. S. Makarenko, V. Y. Tanchuk and V. V. Prokopenko, J. Comput.-Aided Mol. Des., 2005, 19, 453463.

19 VCCLAB, Virtual Computational Chemistry Laboratory, http://www.vcclab.org (accessed 22 May 2013).

20 J. Hine and M. N. Khan, Indian J. Chem., Sect. B: Org. Chem. Incl. Med. Chem., 1992, 31, 427-435.

21 G. M. Steinberg and J. Bolger, J. Am. Pharm. Assoc., 1957, 46, 188-191.

22 R. J. Littel, M. Bos and G. J. Knoop, J. Chem. Eng. Data, 1990, 35, 276-277.

23 F. Wang and L. M. Sayre, J. Am. Chem. Soc., 1992, 114, 248255.

24 A. Gero, J. Med. Chem., 1963, 6, 457-458.

25 F. Bougie and M. C. Iliuta, J. Chem. Eng. Data, 2012, 57, 635-669.

26 J. Zhang, R. Misch, Y. Tan and D. W. Agar, Chem. Eng. Technol., 2011, 34, 1481-1489.

27 I. M. Al-Najjar and M. Green, J. Chem. Soc., Dalton Trans., 1979, 1651-1656.

28 C. W. Hoerr, M. R. McCorkle and A. W. Ralston, J. Am. Chem. Soc., 1943, 65, 328-329.

29 Toxicity Estimation Software Tool, version 4.1, U.S. Environmental Protection Agency, http://www.epa.gov/nrmrl/std/ qsar/qsar.html (accessed 2 August, 2013).

30 Y. Takeuchi, Environ. Res., 1993, 62, 76-80.

31 O. F. Sendur, Y. Turan, S. Bal and A. Gurgan, Inhalation Toxicol., 2009, 21, 210-214.
32 G. D. Ritchie, K. R. Still, W. K. Alexander, A. F. Nordholm, C. L. Wilsom, J. Rossi III and D. R. Mattie, J. Toxicol. Environ. Health, Part B, 2001, 4, 223-312.

33 Sax's Dangerous Properties of Industrial Materials, ed. R. J. Lewis, Van Nostrand Reinhold, New York, 9th edn, 1996.

34 E. J. Gallegos, Anal. Chem., 1981, 53, 187-189.

35 G. G. Hawley, The Condensed Chemical Dictionary, Van Nstrand Reinhold, New York, 9th edn, 1977.

36 Material safety data sheet for $N, N$-dimethylcyclohexylamine, Sigma Aldrich, 2012.

37 Material safety data sheet for $N$-ethylpiperidine, Merck Millipore, 2010.

38 W. B. Wright Jr., J. Org. Chem., 1962, 27, 1042-1045.

39 H. Yoshikawa and K. Kawai, Ind. Health, 1966, 4, 63.

40 Material safety data sheet for $N$-butylpyrrolidine, Sigma Aldrich, 2012.

41 T. Caronna, A. Citterio, T. Crolla, M. Ghirardini and F. Minisci, J. Heterocycl. Chem., 1976, 13, 955-960.

42 Material safety data sheet for $N, N$-dimethylhexylamine, Sigma Aldrich, 2012.

43 Material safety data sheet for $N, N$-dimethylbutylamine, Oxea Chemicals, 2011.

44 W. H. Bell, G. B. Carter and J. Dewing, J. Chem. Soc. C, 1969, 352-354.

45 A. R. Lepley and W. A. Khan, J. Org. Chem., 1966, 31, 20612064.

46 Material safety data sheet for $N, N$-diethylbutylamine, Sigma Aldrich, 2012.

47 N. C. Deno and R. E. Fruit, J. Am. Chem. Soc., 1968, 90, 3502-3506.

48 Material safety data sheet for $N$-methyldipropylamine, Sigma Aldrich, 2010.

49 G. R. Colonna and A. B. Spencer, Fire Protection Guide to Hazardous Materials, National Fire Protection Association, Quincy, Massachusetts, 13th edn, 2002.

50 Material safety data sheet for triethylamine, Sigma Aldrich, 2012.

51 R. E. Watson, A. M. Hafez, J. N. Kremsky and G. O. Bizzigotti, Int. J. Toxicol., 2007, 26, 503-512.

52 P. A. A. Klusener, L. Tip and L. Brandsma, Tetrahedron, 1991, 47, 2041-2064.

53 Material safety data sheet for diisopropylaminoethanol, Sigma Aldrich, 2012.

54 W. B. Burnett, R. L. Jenkins, C. H. Peet, E. E. Dreger and R. Adams, J. Am. Chem. Soc., 1937, 59, 2248-2252.

55 Material safety data sheet for dibutylaminoethanol, Sigma Aldrich, 2013.

56 P. R. Muddasani and V. C. Nannapaneni, PCT Intl WO03101931, 2003.

57 Material safety data sheet for 4,4-diethoxy- $N, N$-dimethyl butan-1-amine, Sigma Aldrich, 2012.

58 G. W. Gribble and C. F. Nutaitis, Synthesis, 1987, 709711.

59 Material safety data sheet for $N, N$-dimethylphenethylamine, Sigma Aldrich, 2013. 
60 P. G. Stone and S. G. Cohen, J. Am. Chem. Soc., 1982, 104, 3435-3440.

61 Material safety data sheet for dipropylamine, Sigma Aldrich, 2012.

62 F. Franks and B. Watson, Trans. Faraday Soc., 1967, 63, 329-334.

63 Material safety data sheet for di-sec-butylamine, Sigma Aldrich, 2012.

64 D. G. Norton, V. E. Haury, F. C. Davis, L. J. Mitchell and S. A. Ballard, J. Org. Chem., 1954, 19, 1054-1066.

65 Material safety data sheet for N-sec-butylpropylamine, TCI Europe, 2012.

66 D. Redmore, J. Org. Chem., 1978, 43, 992-996.

67 Material safety data sheet for $N, N$-dimethylbenzylamine, Sigma Aldrich, 2012.

68 IUCLID Dataset for Toluene, European Commission - European Chemicals Bureau, 2000.

69 V. A. Benignus, Neurotoxicology, 1981, 2, 567-588.

70 E. T. Kimura, D. M. Ebert and P. W. Dodge, Toxicol. Appl. Pharmacol., 1971, 19, 699-704.

71 G. W. Kabalka and S. T. Summers, J. Org. Chem., 1981, 46, 1218-1221.

72 Material safety data sheet for toluene, Merck Millipore, 2012.

73 N. Chang, Z.-Y. Gu and X.-P. Yan, J. Am. Chem. Soc., 2010, 132, 13645-13647.

74 Material safety data sheet for hexane, Sigma Aldrich, 2012.

75 Documentation of the Threshold Limit Values of Biological Exposure Indices, American Conference of Governmental Industrial Hygienists, Cincinnati, Ohio, 6th edn, 1991.

76 Ethel Browning's Toxicity and Metabolism of Industrial Solvents, ed. R. Snyder, Elsevier, New York, 2nd edn, 1987.

77 A. N. Campbell, Can. J. Chem., 1981, 59, 127-131.

78 L. M. Besley and G. A. Bottomley, J. Chem. Thermodyn., 1974, 6, 577-580.

79 S. A. Wieczorek and J. Stecki, J. Chem. Thermodyn., 1978, 10, 177-186.

80 Globally Harmonized System of Classification and Labelling of Chemicals (GHS), United Nations, New York and Geneva, 4th edn, 2011.

81 R. Heijungs, J. Guinee, G. Huppes, R. M. Lankreijer, H. A. Udo de Haes, A. Wegener Sleeswijk, A. M. M. Ansems,
P. G. Eggels, R. van Duin and H. P. de Goede, Environmental Life Cycle Assessment of Products. Guide and Backgrounds, CML, Leiden University, Leiden, 1992.

82 J. R. Baker, M. W. Milke and J. R. Mihelcic, Water Res., 1999, 33, 327-334.

83 D. T. Allen and D. R. Shonnard, Green Engineering: Environmentally Conscious Design of Chemical Processes, PrenticeHall, Upper Saddle River, NJ, 2001.

84 W. P. L. Carter, J. Air Waste Manage. Assoc., 1994, 44, 881899.

85 R. S. Boethling, E. Sommer and D. DiForge, Chem. Rev., 2007, 107, 2207-2227.

86 P. H. Howard, R. S. Boethling, W. M. Stiteler, W. M. Meylan, A. E. Hueber, J. A. Beauman and M. E. Larosche, Environ. Toxicol. Chem., 1992, 11, 593-603.

87 I. Eide-Haugmo, O. G. Brakstad, K. A. Hoff, K. R. Sorheim, E. F. da Silva and H. F. Svendsen, Energy Procedia, 2009, 1, 1297-1304.

88 I. Eide-Haugmo, H. Lepaumier, A. Einbu, K. Vernstad, E. F. da Silva and H. F. Svendsen, Energy Procedia, 2011, 4, 1631-1636.

89 I. Eide-Haugmo, O. G. Brakstad, K. A. Hoff, E. F. da Silva and H. F. Svendsen, Int. J. Greenhouse Gas Control, 2012, 9, 184-192.

90 D. Calamari, R. Da Gasso, S. Galassi, A. Provini and M. Vighi, Chemosphere, 1980, 9, 753-762.

91 M. Kawasaki, Ecotoxicol. Environ. Saf., 1980, 4, 444-454.

92 K. Kawahara, Y. Yakabe, T. Ohide and K. Kida, Chemosphere, 1999, 39, 2007-2018.

93 IUCLID Dataset for Cyclohexyldimethylamine, European Commission - European Chemicals Bureau, 2000.

94 E. M. Davis, H. E. Murray, J. G. Liehr and E. L. Powers, Water Res., 1981, 15, 1125-1127.

95 G. Pasteris, D. Werner, K. Kaufmann and P. Höhener, Environ. Sci. Technol., 2002, 36, 30-39.

96 J. A. Gowland and G. H. Schmid, Can. J. Chem., 1969, 47, 2953-2958.

97 B. Zou and H.-F. Jiang, Chin. J. Chem., 2008, 26, 13091314.

98 S. R. Cheruku, S. Maiti, A. Dorn, B. Scorneaux, A. K. Bhattacharjee, W. Y. Ellis and J. L. Vennerstrom, J. Med. Chem., 2003, 46, 3166-3169. 